\title{
Characterization and Optimization of Fungal L-Asparaginase Isolated from Soil and Medicinal Plants
}

\author{
S. Ranjini Priya (D) and A. Subhashini* \\ Department of Microbiology, Ethiraj College for Women, Egmore, Chennai - 600 008, Tamil Nadu, India.
}

\begin{abstract}
L-asparaginase is a therapeutic enzyme that converts L-asparagine into ammonia and L-aspartate. L-asparaginase is used to treat acute lymphoblastic leukaemia. In food manufacturing industries, it is used to inhibit the acrylamide formation. The current investigation has been performed to isolate L-asparaginase producing fungi from different medicinal plants and soil samples, through serial dilution. A total number of $\mathbf{1 5}$ fungal isolates were obtained from soil samples and $\mathbf{6}$ endophytic fungi isolated from medicinal plants. By performing screening of L-asparaginase $67 \%$ of positive isolates were obtained from endophytes and soil samples. Optimization of L-asparaginase production was performed for parameters such as $\mathrm{pH}$, temperature, carbon and nitrogen source, and it was found that $\mathrm{pH} 6,30^{\circ} \mathrm{C}, 2 \mathrm{~g}$ of glucose, and $1 \mathrm{~g}$ of L-arginine is suitable for maximum enzyme production. By performing Sodium dodecyl sulphate polyacrylamide gel electrophoresis the molecular weight of an enzyme was determined to be approximately $11.2 \mathrm{kDa}$.
\end{abstract}

Keywords: Czapek Dox's medium, Endophytic fungi, L-Asparaginase, Nesslerization

(C) The Author(s) 2022. Open Access. This article is distributed under the terms of the Creative Commons Attribution 4.0 International License which permits unrestricted use, sharing, distribution, and reproduction in any medium, provided you give appropriate credit to the original author(s) and the source, provide a link to the Creative Commons license, and indicate if changes were made. 


\section{INTRODUCTION}

L-Asparaginase is a vital component and it has created an increased awareness in recent years for its anti-carcinogenic potential. ${ }^{1}$ Nonessential amino acid L-asparagine is an essential requirement for both normal and tumor cells. Comparatively, a normal cell does not require much asparagine to survive and it can synthesize the required amount of asparagine on its own. In mutant cells, more precisely lymphatic tumor cells need an enormous quantity of asparagine to retain them in a viable condition with their rapid proliferative growth. ${ }^{2}$ These cells will utilize the asparagine from the diet. Alternatively, tumor cells start to decrease rapidly and die if the dietary supply is terminated because a tumor cell cannot synthesize enough asparagine internally to encourage their continuous growth as shown in (Fig. 1). The continuous decrease in the asparagine level is observed under the supplementation of an enzyme L-asparaginase. ${ }^{3}$ Under physiological conditions the catalytic reaction of $\mathrm{L}$ - Asparaginase is essentially irreversible. ${ }^{4}$ Asparaginase enzyme can be produced by several groups of microorganisms such as bacteria, fungi, and yeast. Also, it is broadly distributed in plants and animal tissues. Asparaginase from above-mentioned sources has been used as an anti-carcinogenic, anti-proliferation and anti-leukemic agent but the application of asparaginase enzyme from bacterial species was initially limited because of its toxicity and various side effects.

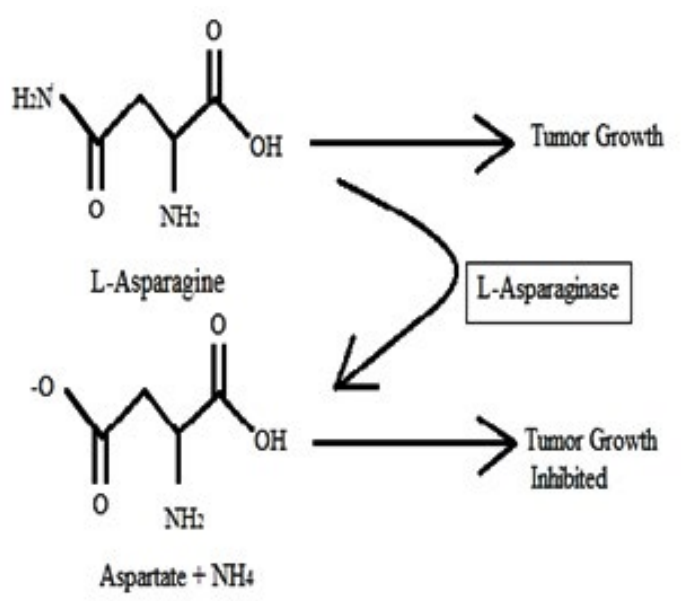

Fig. 1. Schematic illustration of the reaction mechanism of L-asparaginase
Yeast includes, Saccharomyces cerevisiae, Candida utilis and the fungi like Aspergillus niger, Aspergillus lentulus, Aspergillus terreus, Penicillium spp., Rhizopus oryzae. According to FDA, the enzyme obtained from the Aspergillus niger has been considered as a safe and an vital source of an industrial enzyme. This enzyme helps in Reducing the acrylamide formation during the processing of starchy foods at high temperatures. ${ }^{5,6}$ Aim of the study was isolating L-asparaginase producing fungi from the two different environmental sources followed by the optimization to reach the maximum enzyme activity and these enzymes can be applied for the various medical and industrial applications which have been mentioned above.

\section{MATERIALS AND METHODS}

Sabouraud Dextrose Agar (SDA), Modified Czapekdox's agar (McDox), L-asparagine, Nessler's reagent, Phenol red, Whatman No.1 filter paper's and Lowry's reagent were purchased.

\section{Collection of Samples}

Medicinal plants were collected from botanical garden areas in Chennai. Soil samples include Goat milk contaminated soil, Vegetable waste contaminated soil, Dairy milk contaminated soil, Coconut waste dump soil, Fruit peel degraded soil, Soil from a paddy field, Soil from the groundnut field, Garden soil, and soil from different parts of Chennai.

\section{Isolation and Screening of L-Asparaginase}

The leaves were washed for 15 minutes and then immersed in ethanol at different concentrations $(40 \%, 70 \%$, and $90 \%)$ for a one minute with intermittent washing of samples in distilled water. Then the leaves were washed in $40 \%$ Sodium hypochlorite for 1 minute followed by soaking the leaves two times in distilled water. By performing imprint technique the effectiveness of surface sterilization was carried out and the plate that does not show any growth confirmed the effective sterilization. Mortar and pestle were used to ground a surface-sterilized sample's with the addition of 1-2 $\mathrm{ml}$ of sterile saline. These homogenized suspensions were inoculated on to SDA to isolate fungal endophytes. All SDA plates were incubated at room temperature for 4 days. The serial dilution plate method was performed to isolate fungi from soil samples. 
Mycelial plug from SDA plates were inoculated onto McDox agar and it was kept for incubation at room temperature for five days. Controls were prepared without asparagine. Developments of pink zones around the colonies were indicating L Asparaginase Production. ${ }^{7,8}$

\section{L-Asparaginase Production by Submerged Fermentation}

Erlenmeyer flask containing $100 \mathrm{ml}$ of the Czapekdox's liquid medium was taken. The fungal spores were inoculated in the medium and incubated at $30^{\circ} \mathrm{C}$ in an orbital shaker at $250 \mathrm{rpm}$ for a period of 5 days. ${ }^{9,10}$ By carrying out filtration through filter papers the extract was collected and the supernatant act as crude enzyme to estimate the activity of enzyme. ${ }^{4}$

\section{L-Asparaginase Assay}

Enzyme activity of the sample was estimated by determining the amount of ammonia released by the Nesslerization method. ${ }^{11,12}$ and the standard graph was drawn by following protocols. ${ }^{5}$

\section{Protein Estimation}

By performing Lowry method, the amount of protein present in the sample was measured by using standard as Bovine Serum Albumin.

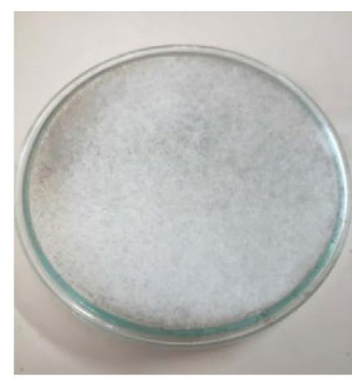

Rhizopus oryzae

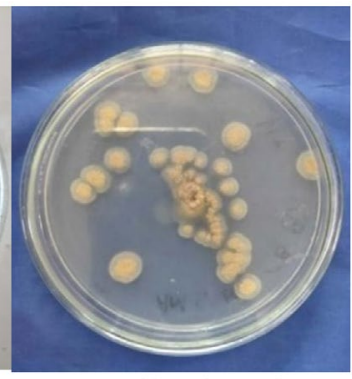

Aspergillus lentulus

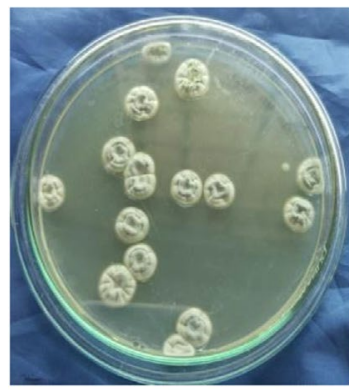

Penicillium $s p$

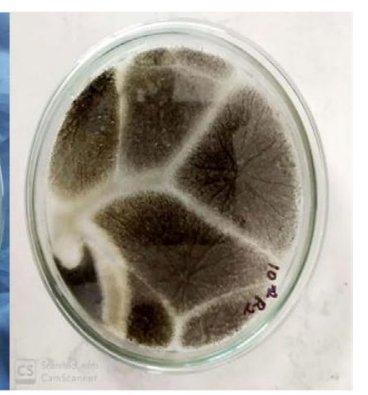

A.niger

\section{Optimization of the Enzyme}

To increase the rate of enzyme activity, submerged fermentation was carried out at different $\mathrm{pH}$, temperature, carbon, and nitrogen source. To obtain the optimum $\mathrm{pH}$ and temperature different $\mathrm{pH}$ such as 4, 5, 6 and temperature such as room temperature, $37^{\circ} \mathrm{C}$ and $50^{\circ} \mathrm{C}$ were set to the production medium. To the production medium with optimized $\mathrm{pH}$ and temperature 1-3 g of Carbon (Glucose) and Nitrogen source (L-Arginine) were added. ${ }^{13,14}$ As discussed earlier, crude enzyme was withdrawn and their enzyme activity measured by the Nesslerization method. Molecular Analysis of Enzyme by SDS-PAGE

Sodium dodecyl sulphate polyacrylamide gel electrophoresis (SDS-PAGE) was performed to find out the molecular weight of an enzyme.

\section{RESULTS}

\section{Isolation of Fungi}

Overall 15 isolates were obtained from soil samples and 6 endophytic fungi isolated from medicinal plants. By seeing macroscopic and microscopic observation genus level identification was performed ${ }^{15-17}$ as shown in fig 2 and 3 and species-level characterization was done by using VITEK ${ }^{\circledR} \mathrm{MS}$.
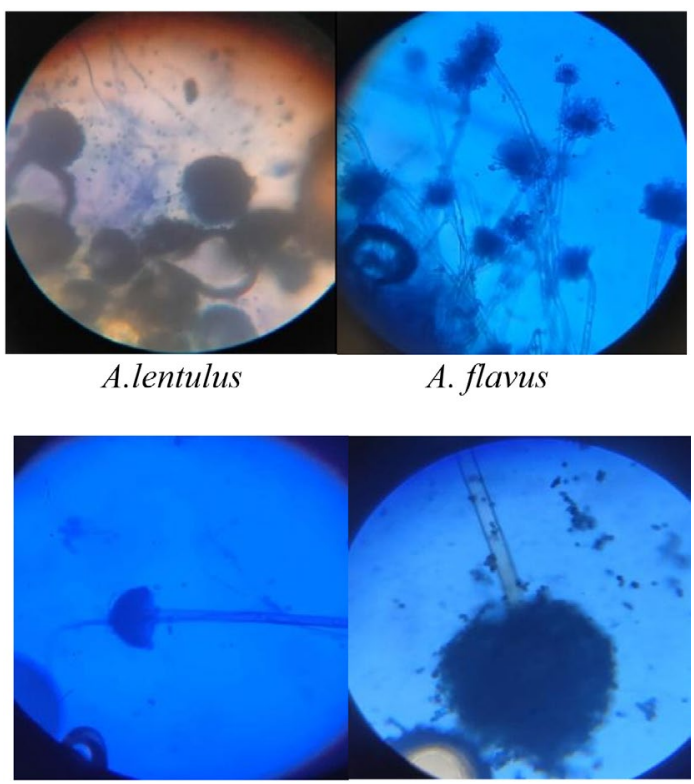

Mucor $s p$

A. niger

Fig. 3. Microscopic appearance of isolated fungi.

Fig. 2. Macroscopic appearance of isolated fungi. 


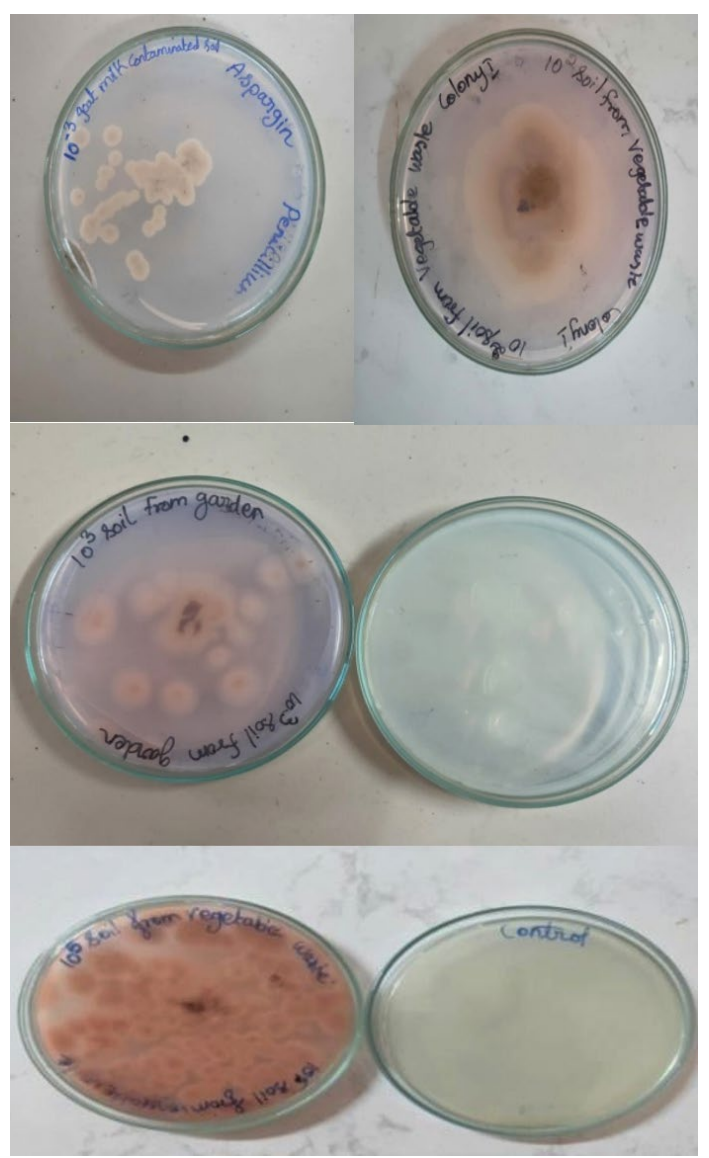

Fig. 4. Pink zone around the colonies.

\section{Screening of Isolates for L-Asparaginase}

Among 21 isolates only 14 showed positive for L-asparaginase activity by developing pink colour zones around the colonies in the plate assay method as shown in (fig 4). Between 14 positive isolates, 13 isolates were obtained from soil samples and one isolate from the medicinal plant. By performing the plate assay method $67 \%$ of positive isolates were obtained from endophytes and soil samples.

\section{Fermentation and L-Asparaginase Assay}

Submerged fermentation was performed and the crude enzyme was extracted for further analytical studies as shown in fig 5 and 6 . Enzyme activity was measured by nesslerization and it was found that Rhizopus spp. from fruit peel degraded soil, Aspergillus spp. from vegetable waste dump soil and Aspergillus lentulus from Annona muricata found to possess high enzyme activity of $1.92 \mathrm{IU} /$ $\mathrm{ml}, 1.4 \mathrm{IU} / \mathrm{ml}$, and $0.73 \mathrm{IU} / \mathrm{ml}$ respectively.

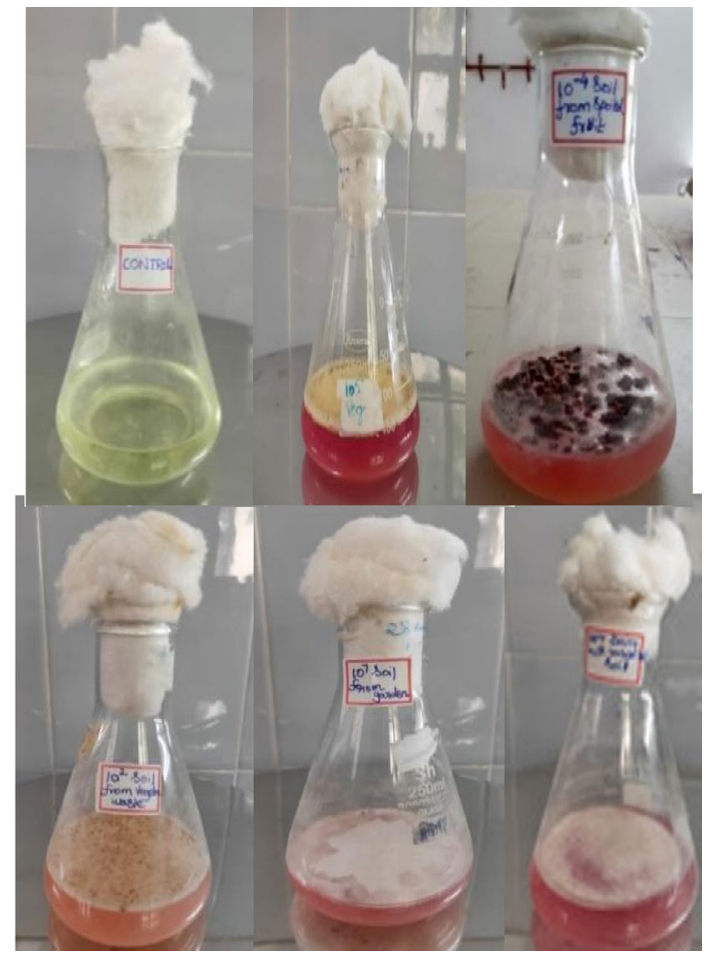

Fig. 5. Submerged fermentation for L-asparaginase production.

\section{Protein Estimation}

The fungi Aspergillus spp., Penicillium spp., and Rhizopus spp. was isolated from Annona muricata, fruit peel degraded soil, garden soil, goat milk contaminated soil, vegetable waste dump soil and dairy milk contaminated soil was found to possess high protein content.

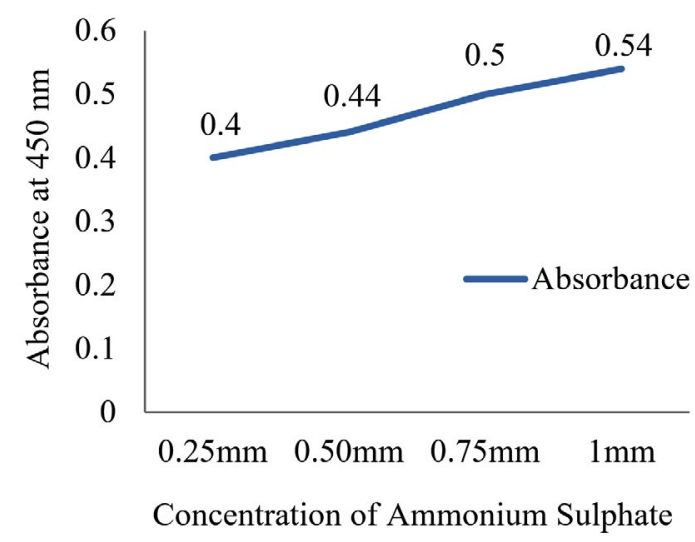

Fig. 6. Concentration vs absorbance graph. 


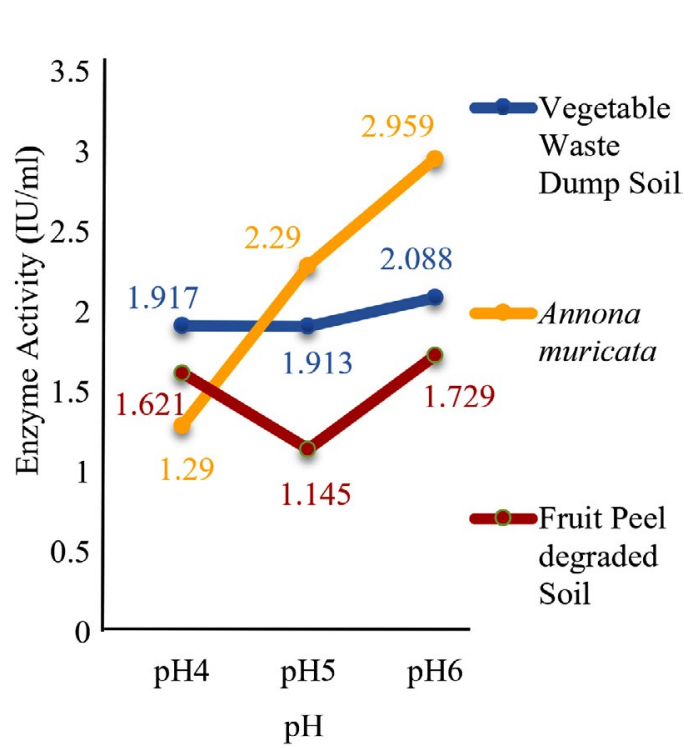

Fig. 7. Effect of $\mathrm{pH}$ on enzyme production.

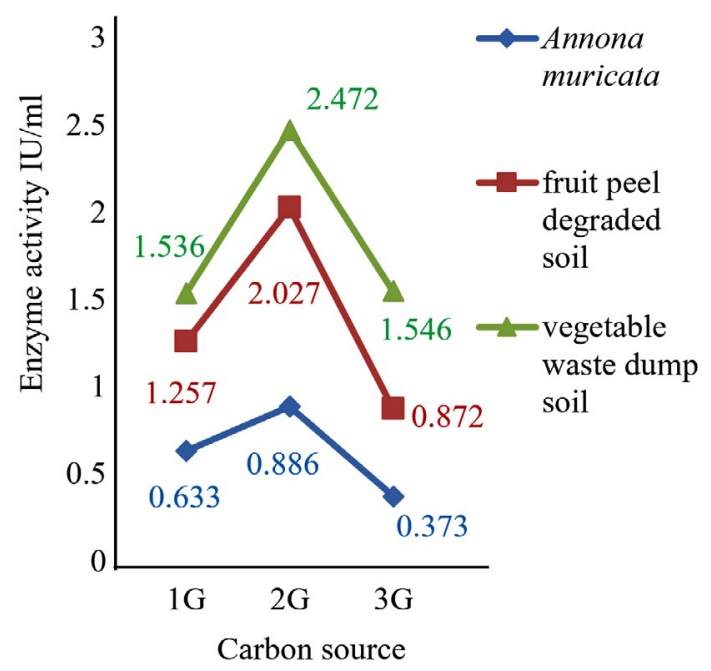

Fig. 9. Effect of carbon source.

\section{Optimization of the Enzyme}

The results showed that the highest activity of the enzyme was achieved at pH 6 and $30^{\circ} \mathrm{C}$. Similarly, $2 \mathrm{~g}$ of glucose and $1 \mathrm{~g}$ of L-Arginine in $50 \mathrm{ml}$ of production medium found to possess high enzyme activity, and it was found to be an optimum concentration as shown in (fig 7-10). Molecular Analysis of Enzyme by SDS-PAGE

The Molecular weight was found to be 11.2 kDa. The band was seen between 6-17 kDa,

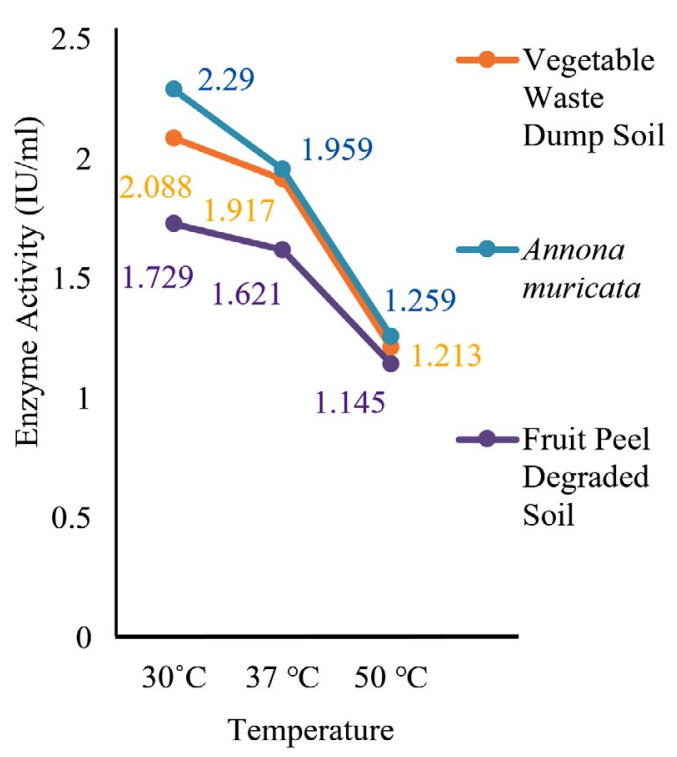

Fig. 8. Effect of temperature on enzyme production.

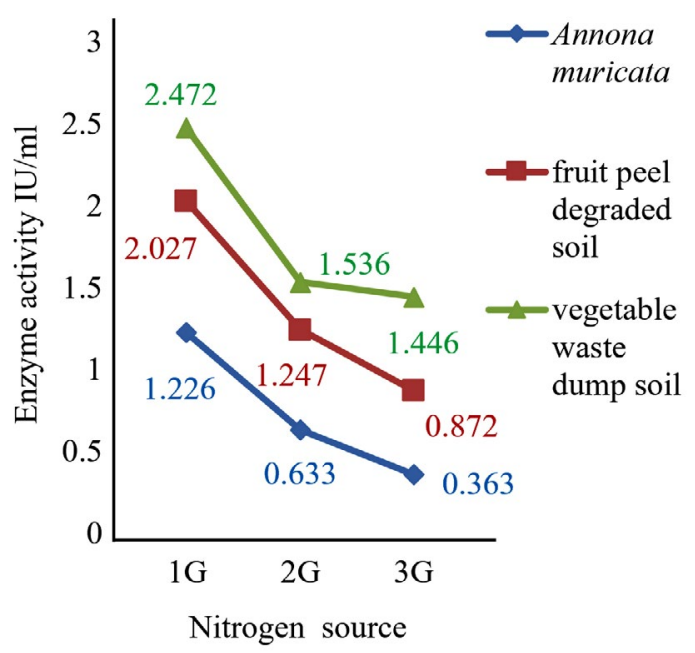

Fig. 10. Effect of nitrogen source.

which confirms the presence of the L-asparaginase enzyme. Lane 1 is Enzyme and Lane 2 is Marker as shown in (fig 11).

\section{DISCUSSION}

In this present work, the selected endophytes and soil samples were found to produce L-Asparaginase which is an essential enzyme for treating malignant cells. The diversity of mycoflora from the leaves of medicinal plant 

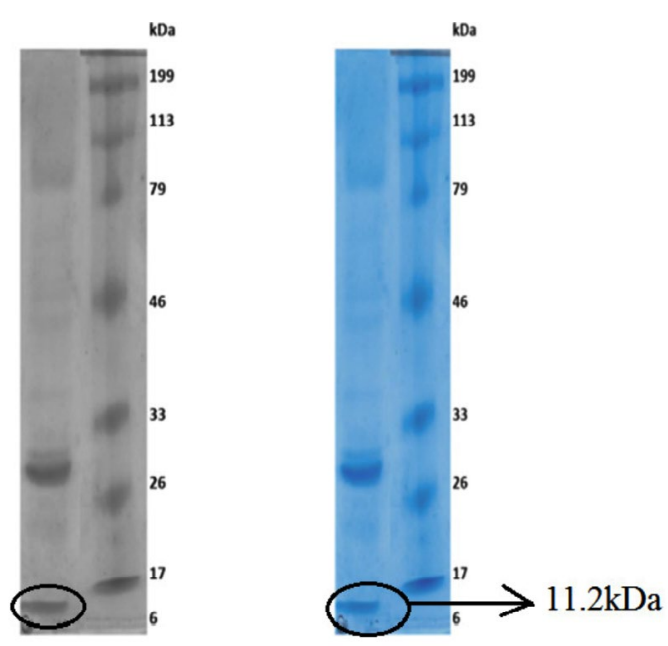

Fig. 11. Enzyme profile in SDS-PAGE.

Annona muricata was found to carry potential source for asparaginase enzyme. Similarly, Benchamin and Sreejai, ${ }^{16}$ have isolated endophytic fungi Aspergillus fumigatus from Annona muricata in the Western Ghats region in Kerala. Both the results indicate that the leaves of the medicinal plant Annona Muricata harbor a rich source of asparaginase producing fungi. As we discussed previously a total number of 15 fungal isolates were obtained from soil samples and 13 have shown positive results. Rhizopus sp. from fruit peel degraded soil was found to produce higher enzyme activity of $1.92 \mathrm{IU} / \mathrm{ml}$. Vipina and Chitra ${ }^{17}$ have isolated 8 fungal isolates from kadalundi mangrove forest soil and all of them have shown positive results. From the total, A.oryzae and Byssochlamys nivea have shown high enzyme activity of $74.5 \mathrm{IU} /$ $\mathrm{ml}$ and $69.3 \mathrm{IU} / \mathrm{ml}$. The difference between these two research works in the concentration of an enzyme, and this is might be due to variation in the soil samples, geographical location, and strain variation.

By performing optimization of the enzyme it was found that $\mathrm{pH} 6$, room temperature, $2 \mathrm{~g}$ of carbon (glucose), and $1 \mathrm{~g}$ of nitrogen source (arginine) have shown maximum enzyme activity. Similarly, optimization of the enzyme was performed by Zia and Bashir, ${ }^{13,14}$ and they have observed that $\mathrm{pH} 6.5$, temperature $35^{\circ} \mathrm{C}, 0.1 \%$ glucose, have shown maximum enzyme activity.
The changes in the above work might be due to differences in carbon and nitrogen source.

From fungi (Aspergillus lentulus) the molecular weight of the enzyme was determined and it was found to be approximately $11.2 \mathrm{kDa}$. Similarly, Elshafei and Hassan ${ }^{18}$ determined the molecular weight of an enzyme from Penicillium brevicompactum and it was found to be $94 \mathrm{kDa}$. The difference in-between two molecular weights might be due to strain variation.

\section{CONCLUSION}

This investigation revealed that L-asparaginase-producing fungi were isolated from medicinal plants and soil samples. These fungi were found to be a potential source for large scale production of L-asparaginase enzyme to manage the needs of industrial and medicinal application

\section{ACKNOWLEDGMENTS}

The authors would like to express their sincere thanks to the Head, Department of Microbiology, Ethiraj College for Women, Tamil Nadu, India who supported and encouraged in this research work.

\section{CONFLICT OF INTEREST}

The authors declare that there is no conflict of interest.

\section{AUTHORS' CONTRIBUTION}

All authors listed have made a substantial, direct and intellectual contribution to the work, and approved it for publication.

\section{FUNDING}

None.

\section{DATA AVAILABILITY}

All datasets generated or analyzed during this study are included in the manuscript.

\section{ETHICS STATEMENT}

Not Applicable.

\section{REFERENCES}

1. Tomar RS, Sharma N, Kaushik S. Isolation and Characterization of L-Asparaginase Extracellular Enzyme Producing Bacteria from Industrial Soil Samples. Int J Pharm Sci Res. 2019:10(11):4937-4941. 
doi: 10.13040/IJPSR.0975-8232.10(11).4937-41

2. Jha SK, Pasrija D, Sinha RK, Singh HR, Nigam VK, Vidyarthi AS. Microbial L-asparaginase: a review on current scenario and future prospects. Int $J$ Pharm Sci Res. 2012;3(9):3076-3090. doi: 10.13040/ IJPSR.0975-8232.3(9).3076-90

3. Ghasemi $Y$, Ebrahiminezhad A, Rasoul-Amini $S$, et al. An optimized medium for Screening of L-asparaginase Production by Escherichia coli. Am J Biochem Biotechnol. 2008;4(4):422-424. doi: 10.3844/ ajbbsp.2008.422.424

4. Thakur M, Lincoln L, Niyonzima FN, More SS. Isolation Purification and Characterization of Fungal Extracellular L-asparaginase from Mucor hiemalis. J Biocatal Biotransformation.2013;2(2)12-14. doi: 10.4172/2324-9099.1000108

5. Devi AL, Ramanjaneyulu R. Isolation of L-Asparaginase Producing Microbial Strains from Soil Samples of Telangana and Andhra Pradesh States, India. Int J Curr Microbiol Appl Sci. 2016;5(10):1105-1113. doi: 10.20546/ijcmas.2016.510.116

6. Naser S, Saber W, El-metwally M, Moustafa M, El-kott A. Fungal assembly of $\mathrm{L}$-asparaginase using Solid-state Fermentation; A Review. Biocell. 2020;44(2):147-155. doi: 10.32604/biocell.2020.09522

7. Chow YY, Ting AS. Endophytic L-asparaginase Producing Fungi from Plants Associated with Anticancer Properties. J Adv Res. 2015;6(6):869-876. doi: 10.1016/j.jare.2014.07.005

8. Hatamzadeh S, Rahnama K, Nasrollahnejad S, et al. Isolation and Identification of L-asparaginase Producing Endophytic Fungi from the Asteraceae Family Plant Species of Iran. Peer J. 2020;8:e8309. doi: 10.7717/peerj.8309

9. Abdel-Razik N, El-Baghdady K, El-Shatoury E, Mohamed N. Isolation, optimization and antitumor activity of I-asparaginase extracted from Pectobacterium carotovorum and Serratia marcescens on human breast adenocarcinoma and human hepatocellular carcinoma cancer cell lines. Asian J Pharm Clin Res. 2019;12(2):332-337. doi: 10.22159/ajpcr. 2019. v12i2.29646

10. Hassan SWM, Farag AM, Beltagy EA. Purification, characterization and anticancer activity of L-asparaginase produced by marine Aspergillus terreus. J Pure App/ Microbiol. 2018;12(4):1845-1854. doi: 10.22207/JPAM.12.4.19

11. Manasa C, Nalini MS. L-Asparaginase activity of fungal endophytes from Tabernaemontana heyneana Wall (Apocynaceae), endemic to the Western Ghats (India). Int Sch Res Notices. 2014;2014:925131. doi: 10.1155/2014/925131

12. Alrumman SA, Mostafa YS, Al-Izran KA, Alfaifi MY, Taha TH, Elbehairi SE. Production and anticancer activity of an L-asparaginase from Bacillus licheniformis isolated from the Red Sea, Saudi Arabia. Sci Rep. 2019;9(1):3756. doi: 10.1038/s41598-019-40512-x

13. Zia MA, Bashir R, Ahmed I, Iftikhar T. Production of L-asparaginase from Aspergillus niger using agro wastes by-products in submerged fermentation process. Jurnal Teknologi. 2013;62(2):47-51. doi: 10.11113/jt.v62.1879

14. Farag AM, Hassan SW, Beltagy EA, El-Shenawy MA. Optimization of production of anti-tumor L-asparaginase by free and immobilized marine Aspergillus terreus. Egypt J Aquat Res. 2015;41(4):295302. doi: 10.1016/j.ejar.2015.10.002

15. Rajeswari, S, Umamaheswari S, Prasanth A, Rajamanikandan KCP. Bioactive potential of endophytic fungi Aspergillus flavus ( $\mathrm{SSO3}$ ) against clinical isolates. Int J Pharm Pharm Sci. 2016;8(9):37-40. doi: 10.22159/ ijpps.2016.v8i9.11466

16. Benchamin D, Sreejai R, Sujitha S, Jensy-Roshan F, Albert C, Rishad KS. Anti-proliferative activity of L-Asparaginase enzyme from fungi on breast cancer. J Pharmacogn Phytochem. 2019;8(1):407-410. https:// www.phytojournal.com/archives/2019/vol8issue1/ PartG/7-6-468-716.pdf. Accessed July 29, 2019

17. Vipina A, Chitra AV. Isolation and Screening of L-Asparaginase Producing Fungi from Kadalundi Mangrove Forest Soil. Int J Sci Res. 2016;5(11):217-218. https://www.worldwidejournals.com/internationaljournal-of-scientific-research-(IJSR)/fileview. php?val=November_2016_1492784776__74.pdf. Accessed July 30, 2019

18. Elshafei AM, Hassan MM, Abouzeid MAE, Mahmoud DA, Elghonemy DH. Purification, characterization and antitumor activity of $\mathrm{L}$-asparaginase from Penicillium brevicompactum NRC 829. Br Microbiol Res J. 2012;2(3):158-174. doi: 10.9734/BMRJ/2012/1735 